\title{
Effects of arsenic trioxide on cell death, reactive oxygen species and glutathione levels in different cell types
}

\author{
YONG HWAN HAN, HWA JIN MOON, BO RA YOU, SUNG ZOO KIM, SUHN HEE KIM and WOO HYUN PARK \\ Department of Physiology, Medical School, Centers for Healthcare Technology Development \\ Institute for Medical Sciences, Chonbuk National University, JeonJu 561-180, Republic of Korea
}

Received July 29, 2009; Accepted September 21, 2009

DOI: 10.3892/ijmm_00000321

\begin{abstract}
Arsenic trioxide (ATO) can regulate many biological functions such as apoptosis and differentiation. We evaluated the effects of ATO on various cell types such as cervical cancer HeLa cells, pulmonary adenocarcinoma Calu-6 and A549 cells, calf pulmonary artery endothelial cells (CPAEC), human umbilical vein endothelial cells (HUVEC) and human pulmonary fibroblast (HPF) cells in relation to cell growth, cell death and reactive oxygen species (ROS) and glutathione (GSH) levels. The growth of HeLa and Calu-6 cells was inhibited by ATO with an $\mathrm{IC}_{50}$ of $\sim 15 \mu \mathrm{M}$ at $24 \mathrm{~h}$. A549 cell growth was not inhibited by $15 \mu \mathrm{M}$ ATO. The susceptibility to ATO in CPAEC and HUVEC was similar to that in HeLa cells. The $\mathrm{IC}_{50}$ of ATO in HPF cells was $\sim 40 \mu \mathrm{M}$. ATO induced apoptosis in HeLa, CPAEC and HUVEC, which was accompanied by the loss of mitochondrial membrane potential $\left(\Delta \Psi_{\mathrm{m}}\right)$. However, ATO did not strongly trigger apoptosis in Calu-6, A549 and HPF cells. ATO increased or decreased the ROS level including $\mathrm{O}_{2}{ }^{-}$and $\mathrm{GSH}$ levels depending on the incubation dose and cell type. In conclusion, ATO differentially affected cell growth inhibition and death depending on the incubation dose and cell type. The changes in ROS and GSH levels by ATO were not tightly correlated with the level of cell death. Our present
\end{abstract}

Correspondence to: Dr Woo Hyun Park, Department of Physiology, Medical School, Chonbuk National University, JeonJu 561-180, Republic of Korea

E-mail: parkwh71@chonbuk.ac.kr

Abbreviations: ATO, arsenic trioxide $\left(\mathrm{As}_{2} \mathrm{O}_{3}\right)$; CPAEC, calf pulmonary arterial endothelial cells; HUVEC, human umbilical vein endothelial cells; HPF, human pulmonary fibroblast; ROS reactive oxygen species; MMP $\left(\Delta \Psi_{\mathrm{m}}\right)$, mitochondrial membrane potential; FBS, fetal bovine serum; MTT, 3-(4,5-dimethylthiazol-2yl)-2,5-diphenyltetrazolium bromide; FITC, fluorescein isothiocyanate; $\mathrm{H}_{2}$ DCFDA, 2',7'-dichlorodihydrofluorescein diacetate; DHE, dihydroethidium; GSH, glutathione; CMFDA, 5-chloromethylfluorescein diacetate

Key words: arsenic trioxide, cell, apoptosis, reactive oxygen species, glutathione data provide useful information for the action of ATO in various cell types in relation to cell growth, cell death, ROS and GSH levels.

\section{Introduction}

Arsenic trioxide (ATO; $\mathrm{As}_{2} \mathrm{O}_{3}$ ) has been reported to induce complete remission without severe marrow suppression in patients with relapsed or refractory acute promyelocytic leukemia (APL) (1). The antiproliferative effect of ATO is not limited to APL cells, but can also be observed in a variety of hematological malignancies (2-4). Accumulating evidence indicates that ATO can affect many biological functions such as cell proliferation, apoptosis, differentiation, and angiogenesis in cell lines derived from renal (5), head and neck (6), ovarian (7), prostate $(7)$, hepatoma $(8,9)$, bladder $(10)$, colon (11), lung (12), breast (13), cervical (14) and gastric (15) cancer cells. ATO is a mitochondrial toxin and induces loss of the mitochondrial transmembrane potential $(2,5,16)$. Therefore, it is believed to induce apoptosis in tumor cells by affecting mitochondria and the production of reactive oxygen species (ROS).

ROS include hydrogen peroxide $\left(\mathrm{H}_{2} \mathrm{O}_{2}\right)$, superoxide anions $\left(\mathrm{O}_{2}{ }^{-*}\right)$ and hydroxyl radicals $\left({ }^{\circ} \mathrm{OH}\right)$. These molecules have recently been implicated in many important processes such as transcription factor activation, gene expression, differentiation and cellular proliferation (17-19). Glutathione (GSH) is the main non-protein antioxidant in cells; it provides electrons for enzymes such as glutathione peroxidase, which reduce $\mathrm{H}_{2} \mathrm{O}_{2}$ to $\mathrm{H}_{2} \mathrm{O}$. GSH has been shown to be crucial for regulation of cell proliferation, cell cycle progression and apoptosis $(20,21)$, and it is known to protect cells from toxic insult by detoxifying toxic metabolites of drugs and ROS (22).

In the present study, we evaluated the effects of ATO on various cell types such as cervical cancer HeLa cells, pulmonary adenocarcinoma Calu-6 and A549 cells, CPAEC, HUVEC and HPF cells in relation to cell growth, cell death and ROS and GSH levels.

\section{Materials and methods}

Cell culture. Human cervix adenocarcinoma HeLa cells and human pulmonary adenocarcinoma Calu-6 and A549 cells from the ATCC (American Type Culture Collection), calf 
pulmonary artery endothelial cells (CPAEC) from KCLB (Korean Cell Line Bank), primary human umbilical vein endothelial cells (HUVEC) and human pulmonary fibroblast (HPF) cells from PromoCell GmbH (Heidelberg, Germany) were maintained in a humidified incubator containing $5 \%$ $\mathrm{CO}_{2}$ at $37^{\circ} \mathrm{C}$. HeLa, Calu-6 and A549 and CPAEC were cultured in RPMI-1640 supplemented with $10 \%$ fetal bovine serum (FBS) and 1\% penicillin-streptomycin (Gibco BRL, Grand Island, NY). These cell lines were routinely grown in 100-mm plastic tissue culture dishes (Nunc, Roskilde, Denmark) and harvested with a solution of trypsin-EDTA (Gibco BRL) while in a logarithmic phase of growth. HUVEC and HPF cells were cultured in complete endothelial cell growth medium and fibroblast growth medium 2 (PromoCell), respectively. HUVEC and HPF cells were washed and detached with HepesBSS (30 mM Hepes), trypsin-EDTA and trypsin neutralization solution (Promo Cell). HUVEC and HPF cells were used between passages four and six.

Reagents. ATO purchased from Sigma-Aldrich Chemical Co. (St. Louis, MO) was dissolved in $1.65 \mathrm{M} \mathrm{NaOH}$ at $100 \mathrm{mM}$ as a stock solution, which was wrapped in foil and kept at $-4^{\circ} \mathrm{C}$.

Cell growth assay. The effect of ATO on cell growth was determined by measuring 3-(4,5-dimethylthiazol-2-yl)-2,5diphenyltetrazolium bromide (MTT) dye absorbance of living cells as previously described (2). In brief, cells (5x104/well) were seeded in 96-well microtiter plates (Nunc) for an MTT assay. After exposure to the indicated amounts of ATO for $24 \mathrm{~h}, 20 \mu \mathrm{l}$ of MTT (Sigma) solution ( $2 \mathrm{mg} / \mathrm{ml}$ in PBS) was added to each well of 96 -well plates. The plates were incubated for an additional $4 \mathrm{~h}$ at $37^{\circ} \mathrm{C}$. MTT solution in the medium was aspirated off, and $200 \mu 1$ of DMSO was added to each well to solubilize the formazan crystals formed in the viable cells. Optical density was measured at $570 \mathrm{~nm}$ using a microplate reader (Spectra Max 340, Molecular Devices Co., Sunnyvale, CA).

Annexin $V$ staining. Apoptosis was determined by staining cells with annexin V-fluorescein isothiocyanate (FITC) $(E x / E m=488 \mathrm{~nm} / 519 \mathrm{~nm})$ as previously described (23). In brief, $1 \times 10^{6}$ cells in a $60-\mathrm{mm}$ culture dish (Nunc) were incubated with the indicated amounts of ATO for $24 \mathrm{~h}$. Cells were washed twice with cold PBS and then resuspended in $500 \mu \mathrm{l}$ of binding buffer (10 mM HEPES/NaOH, pH 7.4, $140 \mathrm{mM} \mathrm{NaCl}$ and $2.5 \mathrm{mM} \mathrm{CaCl}_{2}$ ) at a concentration of $1 \times 10^{6}$ cells $/ \mathrm{ml}$. Five microliters of annexin V-FITC (Pharmingen, San Diego, CA) was then added to the cells, which were analyzed with a FACStar flow cytometer (Becton Dickinson).

Measurement of mitochondrial membrane potential (MMP) $\left(\Delta \Psi_{m}\right)$. MMP $\left(\Delta \Psi_{\mathrm{m}}\right)$ levels were measured by the Rhodamine 123 fluorescent dye $(E x / E m=485 \mathrm{~nm} / 535 \mathrm{~nm}$; Sigma) as previously described (24). In brief, $1 \times 10^{6}$ cells in a $60-\mathrm{mm}$ culture dish were incubated with the indicated amounts of ATO for $24 \mathrm{~h}$. Cells were washed twice with PBS and incubated with Rhodamine $123(0.1 \mu \mathrm{g} / \mathrm{ml}$; Sigma $)$ at $37^{\circ} \mathrm{C}$ for $30 \mathrm{~min}$. Rhodamine 123 staining intensity was determined by a FACStar flow cytometer. Rhodamine 123negative cells indicate the loss of $\operatorname{MMP}\left(\Delta \Psi_{\mathrm{m}}\right)$ in cells.

Detection of intracellular ROS and O2- levels. Intracellular ROS such as $\mathrm{H}_{2} \mathrm{O}_{2}$ and $\cdot \mathrm{OH}$ were detected by means of an oxidation-sensitive fluorescent probe dye, 2',7'-dichlorodihydrofluorescein diacetate $\left(\mathrm{H}_{2} \mathrm{DCFDA} ; \mathrm{Ex} / \mathrm{Em}=495 \mathrm{~nm} /\right.$ 529 nm; Invitrogen Molecular Probes, Eugene, OR) (25). $\mathrm{H}_{2}$ DCFDA is poorly selective for $\mathrm{O}_{2}{ }^{-}$. In contrast, dihydroethidium (DHE, Ex/Em=518 nm/605 nm; Invitrogen Molecular Probes) is highly selective for $\mathrm{O}_{2}{ }^{-}$among ROS. In brief, $1 \times 10^{6}$ cells in a $60-\mathrm{mm}$ culture dish were incubated with the indicated amounts of ATO for $24 \mathrm{~h}$. Cells were then washed in PBS and incubated with $20 \mu \mathrm{M} \mathrm{H}_{2}$ DCFDA or $\mathrm{DHE}$ at $37^{\circ} \mathrm{C}$ for $30 \mathrm{~min}$ according to the manufacturer's instructions. DCF and DHE fluorescence was detected using a FACStar flow cytometer. ROS and $\mathrm{O}_{2}{ }^{*-}$ levels were expressed as mean fluorescence intensity (MFI), which was calculated by CellQuest software.

Detection of the intracellular GSH. Cellular GSH levels were analyzed using 5-chloromethylfluorescein diacetate (CMFDA, Ex/Em=522 nm/595 nm; Molecular Probes) as previously described (25). In brief, $1 \times 10^{6}$ cells in a $60-\mathrm{mm}$ culture dish were incubated with the indicated amounts of ATO for $24 \mathrm{~h}$. Cells were then washed with PBS and incubated with $5 \mu \mathrm{M} \mathrm{CMFDA}$ at $37^{\circ} \mathrm{C}$ for $30 \mathrm{~min}$. CMF fluorescence intensity was determined using a FACStar flow cytometer. CMF levels in viable cells without GSH-depleted cells were expressed as mean fluorescence intensity (MFI), which was calculated by CellQuest software.

\section{Results}

Effects of ATO on the growth of various cell types. We examined the effect of ATO on the growth of different cell types at $24 \mathrm{~h}$ by an MTT assay (Fig. 1). Treatment with ATO differentially inhibited cell growth depending on the incubation dose and cell type. The growth of cervical cancer HeLa cells was dose-dependently inhibited by ATO with an $\mathrm{IC}_{50}$ of $\sim 15 \mu \mathrm{M}$ (Fig. 1A). The growth of Calu-6 lung cancer cells was also dose-dependently reduced by ATO with an $\mathrm{IC}_{50}$ of $\sim 15 \mu \mathrm{M}$ (Fig. 1B) whereas that of A549 lung cancer cells was not inhibited by $15 \mu \mathrm{M}$ ATO (Fig. 1C). Even 10-20 $\mu \mathrm{M}$ ATO slightly increased A549 cell growth, and only $50 \mu \mathrm{M}$ ATO mildly inhibited A549 cell growth (Fig. 1C). ATO inhibited the growth of normal CPAEC in a dose-dependent manner with an $\mathrm{IC}_{50}$ of $\sim 15 \mu \mathrm{M}$ (Fig. 1D). In relation to primary normal cells, ATO dose-dependently inhibited the growth of HUVEC with an $\mathrm{IC}_{50}$ of $\sim 20-30 \mu \mathrm{M}$ (Fig. 1E) whereas 1-10 $\mu \mathrm{M}$ ATO significantly increased the growth of HPF cells (Fig. 1F). The $\mathrm{IC}_{50}$ of ATO in HPF cells was $\sim 40 \mu \mathrm{M}$ (Fig. 1F).

Effects of ATO on cell death and MMP $\left(\Delta \Psi_{m}\right)$ of various cell types. Next, we determined whether ATO induces apoptosis in cells using an annexin $\mathrm{V}$-staining assay. The numbers of annexin V-stained cells were dose-dependently increased in 
A

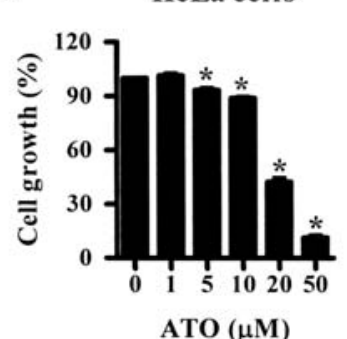

D

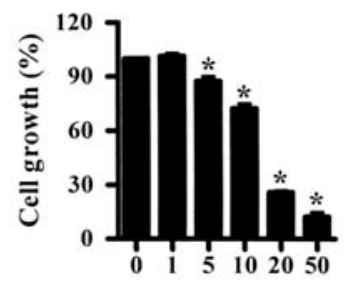

ATO $(\mu \mathbf{M})$
B

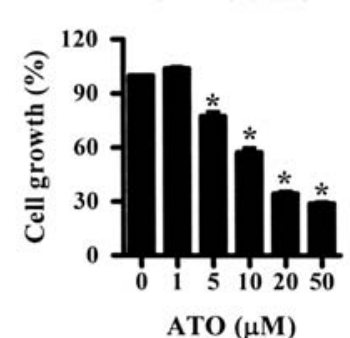

$\mathbf{E}$

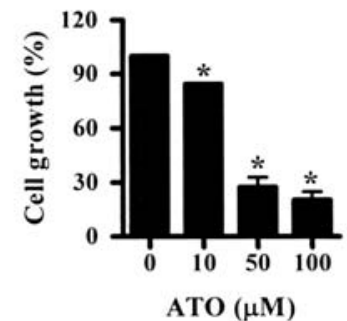

C

A549 cells

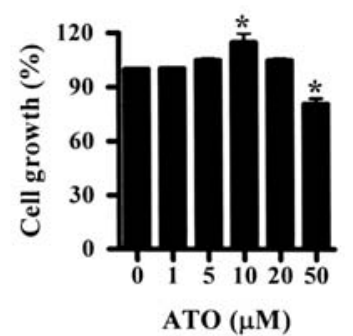

F

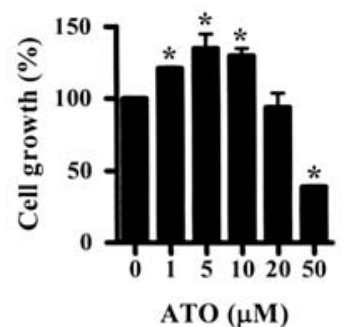

Figure 1. Effects of ATO on the growth of various cell types (A-F). Exponentially growing cells were treated with the indicated concentrations of ATO for $24 \mathrm{~h}$. Cell growth was assessed by an MTT assay. The results shown represent the mean of at least three experiments; bar, SD. The Student's t-test was used for parametric data. The statistical significance was defined as * $\mathrm{p}<0.05$, compared with the ATO-untreated control group.
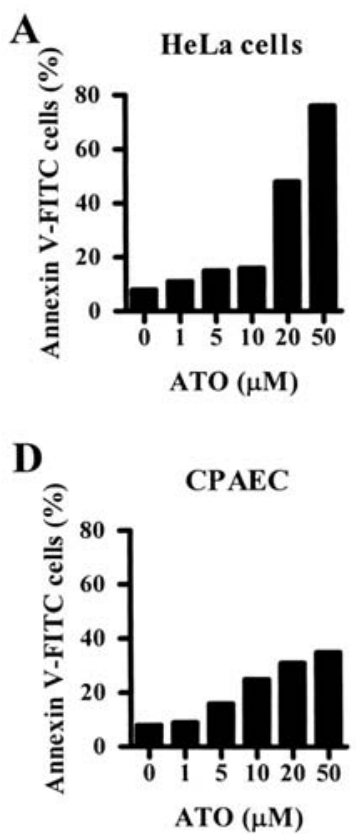

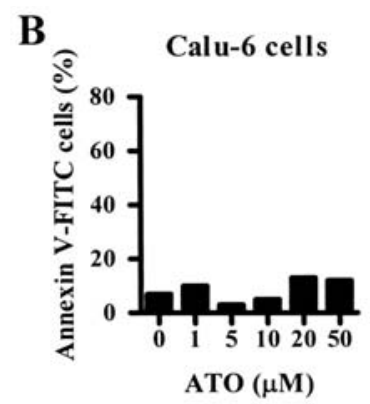

$\mathbf{E}$

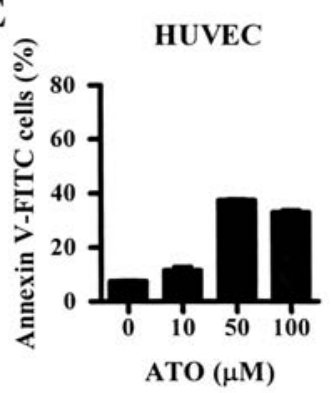

C

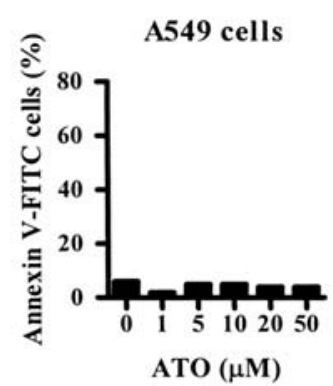

$\mathbf{F}$

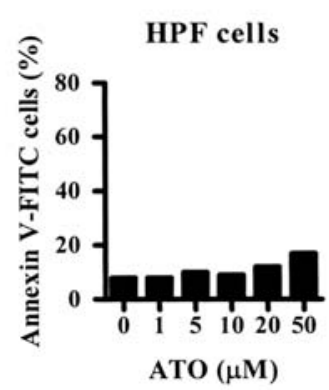

Figure 2. Effects of ATO on the cell death of various cell types (A-F). Exponentially growing cells were treated with the indicated concentrations of ATO for $24 \mathrm{~h}$. The percentages of annexin V-positive-stained cells were measured using a FACStar flow cytometer.

ATO-treated HeLa cells (Fig. 2A). At a 50- $\mu \mathrm{M}$ dose of ATO, the number of annexin $\mathrm{V}$-stained cells was increased $\sim 65 \%$ compared with the ATO-untreated control HeLa cells (Fig. 2A). Treatment with 20 or $50 \mu \mathrm{M}$ ATO seemed to increase the number of annexin V-stained cells in Calu- 6 cells, but the number was not large (Fig. 2B). In ATO-treated A549 cells, the number of annexin $\mathrm{V}$-stained cells was not affected (Fig. 2C). ATO increased the number of annexin V-stained cells in both CPAEC and HUVEC (Fig. 2D and E). At a 50- $\mu \mathrm{M}$ dose of ATO, the number of annexin V-stained cells in both cells was increased $\sim 30 \%$ compared with the ATO-untreated control cells (Fig. 2D and E). In ATO-treated HPF cells, only $50 \mu \mathrm{M}$ ATO slightly increased the number (Fig. 2F).

Since apoptosis is closely related to the collapse of MMP $\left(\Delta \Psi_{\mathrm{m}}\right)(26)$, we assessed the effect of ATO on MMP $\left(\Delta \Psi_{\mathrm{m}}\right)$ in cells using Rhodamine 123 . Treatment with $>5 \mu \mathrm{M}$ ATO induced the loss of MMP $\left(\Delta \Psi_{\mathrm{m}}\right)$ in HeLa and Calu- 6 cells (Fig. 3A and B). At a $50-\mu \mathrm{M}$ dose of ATO, the percentages 
A

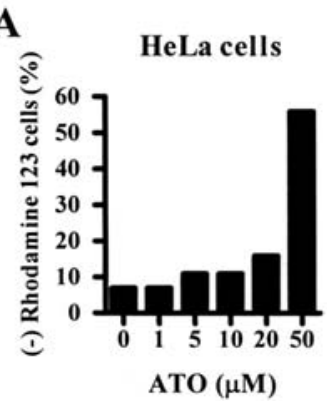

D

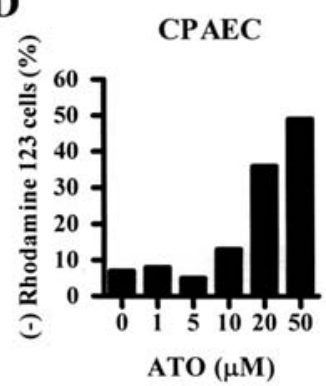

B

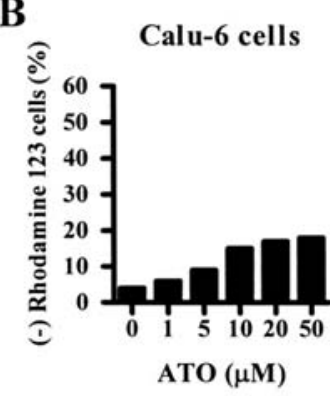

$\mathbf{E}$

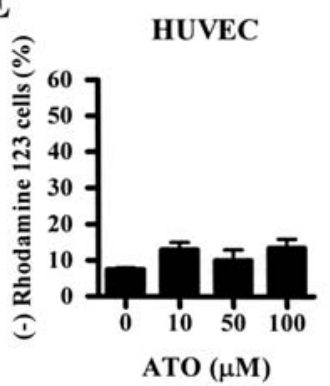

C

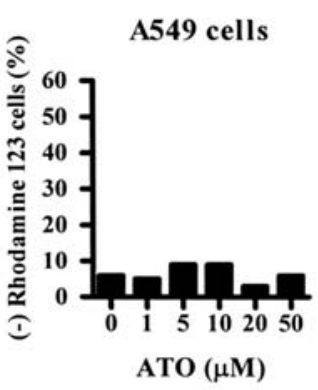

F

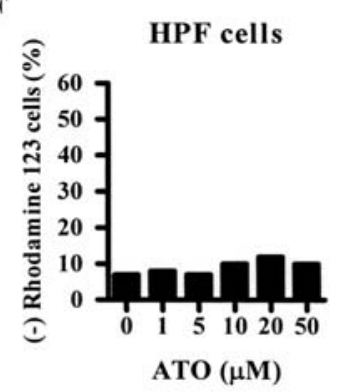

Figure 3. Effects of ATO on MMP $\left(\Delta \Psi_{\mathrm{m}}\right)$ in various cell types (A-F). Exponentially growing cells were treated with the indicated concentrations of ATO for $24 \mathrm{~h}$. The percentages of Rhodamine 123-negative [MMP $\left(\Delta \Psi_{\mathrm{m}}\right)$ loss] cells were measured using a FACStar flow cytometer.

A

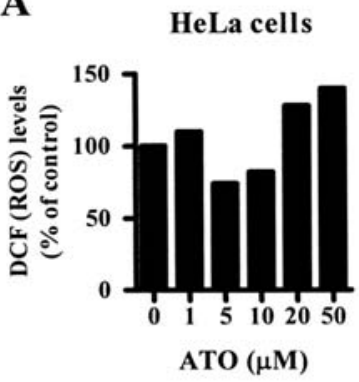

D

CPAEC

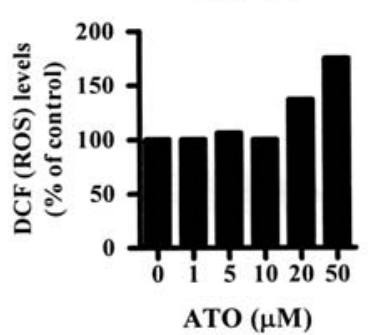

B

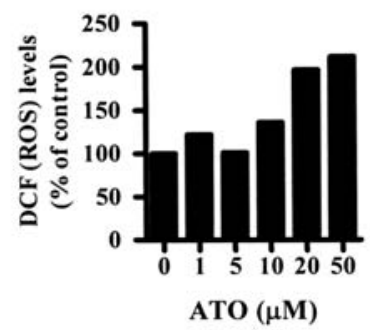

$\mathbf{E}$

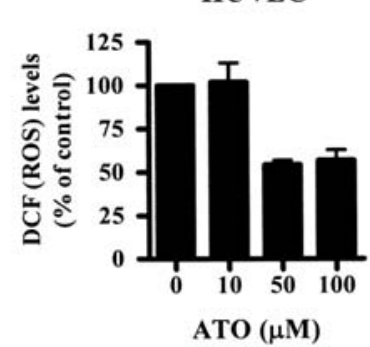

C

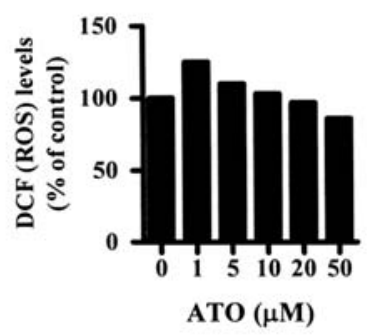

$\mathbf{F}$

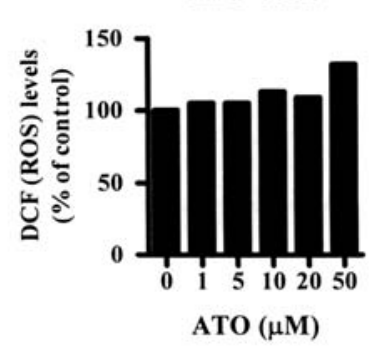

Figure 4. Effects of ATO on ROS levels in various cell types (A-F). Exponentially growing cells were treated with the indicated concentrations of ATO for 24 h. ROS (DCF) levels in cells were measured using a FACStar flow cytometer. Graphs indicate DCF (ROS) levels (\%) in cells compared with each group of control cells.

of MMP $\left(\Delta \Psi_{\mathrm{m}}\right)$ loss were 50 and $13 \%$ in HeLa and Calu-6 cells compared with ATO-untreated control cells, respectively (Fig. 3A and B). ATO did not affect the MMP $\left(\Delta \Psi_{\mathrm{m}}\right)$ loss in A549 cells (Fig. 3C). Treatment with $>10 \mu \mathrm{M}$ ATO seemed to induce the loss of MMP $\left(\Delta \Psi_{\mathrm{m}}\right)$ in both CPAEC and HUVEC (Fig. 3D and E). However, ATO did not strongly induce MMP $\left(\Delta \Psi_{\mathrm{m}}\right)$ loss in HUVEC (Fig. 3E).
In ATO-treated HPF cells, ATO did not affect the MMP $\left(\Delta \Psi_{\mathrm{m}}\right)$ loss (Fig. 3F).

Effects of ATO on intracellular ROS in various cell types. To assess levels of intracellular ROS in ATO-treated cells at $24 \mathrm{~h}$, we used $\mathrm{H}_{2}$ DCFDA and DHE. Treatment with ATO differentially affected ROS levels depending on the incubation 
A

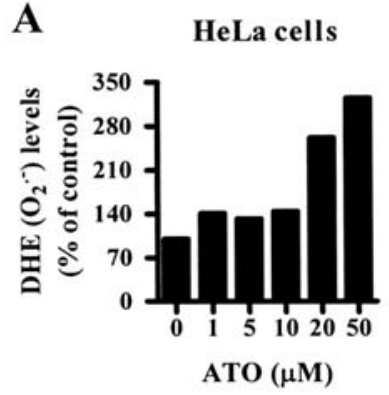

D

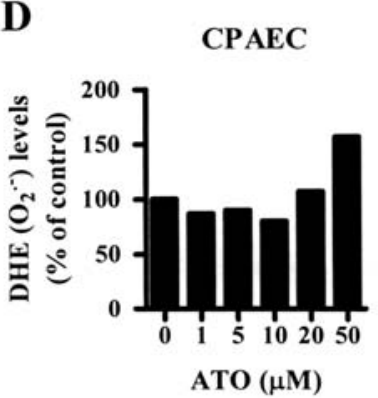

B

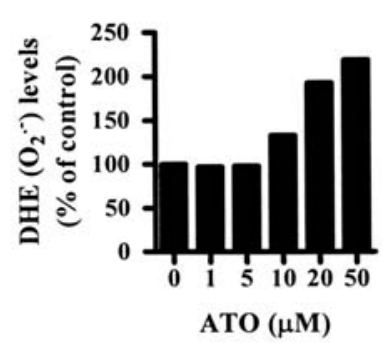

$\mathbf{E}$

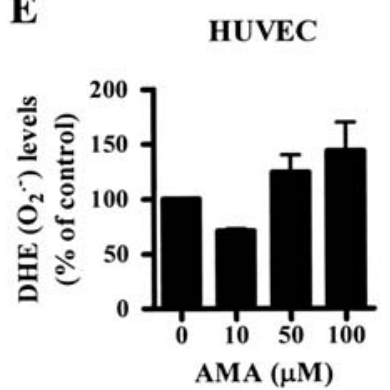

C

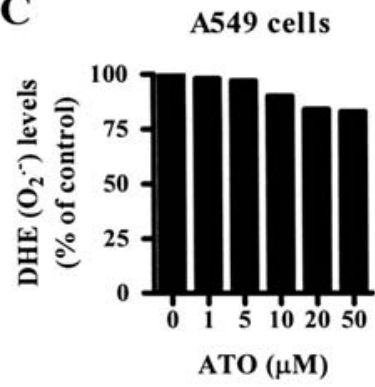

$\mathbf{F}$

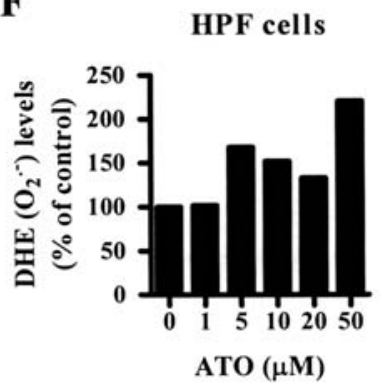

Figure 5. Effects of ATO on $\mathrm{O}_{2}^{--}$levels in various cell types (A-F). Exponentially growing cells were treated with the indicated concentrations of ATO for 24 h. DHE $\left(\mathrm{O}_{2}^{-}\right)$levels in cells were measured using a FACStar flow cytometer. Graphs indicate DHE $\left(\mathrm{O}_{2}{ }^{-}\right)$levels $(\%)$ in cells compared with each group of control cells.

dose and cell type (Fig. 4). While 5 or $10 \mu \mathrm{M}$ ATO decreased ROS in HeLa cells, 20 or $50 \mu \mathrm{M}$ ATO increased the level of ROS (Fig. 4A). Treatment with ATO generally increased the ROS level in Calu-6 cells (Fig. 4B). Treatment with $1 \mu \mathrm{M}$ ATO increased the ROS level in A549 cells whereas $50 \mu \mathrm{M}$ ATO decreased the ROS level (Fig. 4C). The relatively higher doses of ATO increased the ROS level in CPAEC (Fig. 4D) and decreased the ROS level in HUVEC (Fig. 4E). In addition, the higher dose of $50 \mu \mathrm{M}$ ATO increased the ROS level in HPF cells (Fig. 4F). The level of red fluorescence derived from DHE, which reflected $\mathrm{O}_{2}{ }^{-}$accumulation, was increased in ATO-treated HeLa and Calu- 6 cells (Fig. 5A and B). In contrast, all the tested doses of ATO decreased $\mathrm{O}_{2}{ }^{-}$levels in A549 cells (Fig. 5C). While the dose of $10 \mu \mathrm{M}$ ATO decreased $\mathrm{O}_{2}{ }^{-}$levels in both CPAEC and HUVEC, higher doses of ATO increased the levels (Fig. 5D and E). Treatment with $>5 \mu \mathrm{M}$ ATO increased $\mathrm{O}_{2}{ }^{-}$levels in HPF cells but the increase was not dose-dependent (Fig. 5F).

Effects of ATO on the intracellular GSH levels in various cell types. Next, we analyzed the changes in GSH levels in cells without GSH-depleted cells using CMF fluorescence dye. Treatment with ATO increased or decreased GSH levels depending on the incubation dose and cell type (Fig. 6). Treatment with $<20 \mu \mathrm{M}$ ATO increased GSH levels in HeLa cells, and $50 \mu \mathrm{M}$ ATO deceased the level (Fig. 6A). In contrast, lower doses of ATO decreased GSH levels in Calu-6 cells whereas higher doses of ATO increased the levels (Fig. 6B). In ATO-treated A549 cells, the GSH level was not strongly altered (Fig. 6C). Treatment with $>20 \mu \mathrm{M}$ ATO decreased GSH levels in CPAEC (Fig. 6D), and $>10 \mu \mathrm{M}$ ATO decreased the levels in HUVEC (Fig. 6E). The relatively lower doses of 1-10 $\mu \mathrm{M}$ ATO increased GSH levels in HPF cells, while higher doses of ATO did not change the level (Fig. 6F).

\section{Discussion}

In the present study, we focused on evaluating the effects of ATO on various cell types in relation to cell growth, cell death, and ROS and GSH levels, even though there have been many theories and proposed potential targets regarding the mechanism of the anticancer effect in response to ATO. The growth of HeLa and Calu-6 cells was dose-dependently inhibited by ATO with an $\mathrm{IC}_{50}$ of $\sim 15 \mu \mathrm{M}$. The susceptibility to ATO in HeLa and Calu-6 cells is generally lower than that in leukemia and myeloma cell lines $(2,27)$, and is similar to that in other solid tumors such as ovarian cancer, colon cancer, cervical cancer, renal cell carcinoma and breast cancer cell lines $(5,28)$. However, A549 cell growth was not inhibited by $15 \mu \mathrm{M}$ ATO at $24 \mathrm{~h}$. Even at $10-20 \mu \mathrm{M}$, ATO slightly increased A549 cell growth. A549 cells were considered to be very resistant to ATO. In relation to normal and primary cells, the susceptibility to ATO in CPAEC and HUVEC was similar to that shown in HeLa and Calu-6 cells. Notably, 1$10 \mu \mathrm{M}$ ATO significantly increased the growth of HPF cells, and the $\mathrm{IC}_{50}$ of ATO in HPF cells was $\sim 40 \mu \mathrm{M}$. The differential susceptibility to ATO of the various cell types depended on the incubation dose and cell type. Even the susceptibility to ATO was different in cells derived from tissues of the same origin (Calu-6, A549 and HPF) and was also diverse in normal and primary cell types (CPAEC, HUVEC and HPF). Therefore, before using ATO as a therapeutic agent in cancer patients, we must consider the differential mechanisms involving the anticancer effect of ATO and the specificity of the target tumor. 

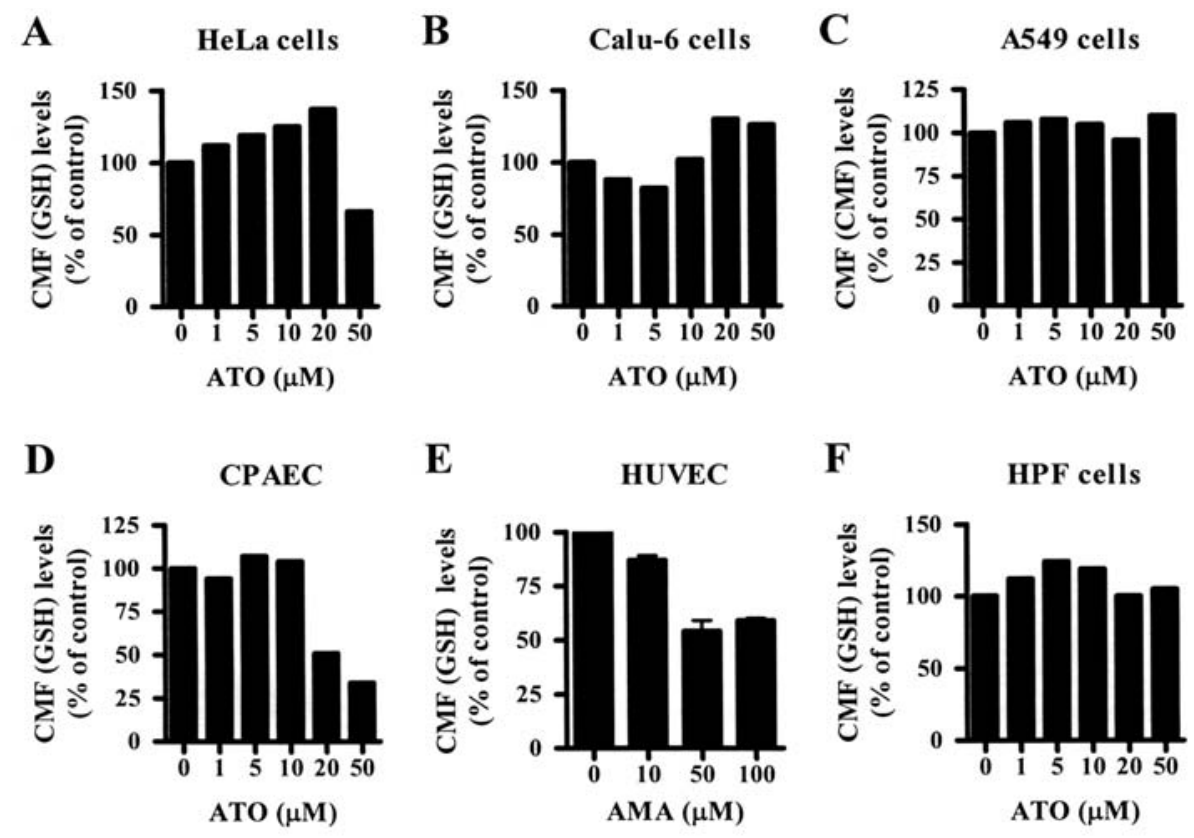

Figure 6. Effects of ATO on GSH levels in various cell types (A-F). Exponentially growing cells were treated with the indicated concentrations of ATO for 24 h. GSH (CMF) levels in cells were measured using a FACStar flow cytometer. Graphs indicate GSH (CMF) levels (\%) in cells except (-) CMF (GSH-depleted) cells compared with each group of control cells.

ATO dose-dependently induced apoptosis in HeLa, CPAEC and HUVEC as evidenced by the annexin V staining of cells. However, ATO did not strongly trigger apoptosis in Calu-6, A549 and HPF cells. These results seem to correlate with the results of the growth inhibition by ATO. However, ATO-treated Calu- 6 cells showed dissimilar results. Since suppression of cell growth by ATO can be explained by its capacity to affect arrest during the cell cycle, we examined cell cycle distributions in ATO-treated Calu- 6 cells and observed that ATO induced a G2 phase arrest of the cell cycle (data not shown), which could be considered a major pathway by which the growth of Calu-6 cells is suppressed. However, we could not exclude other cell death pathways such as necrosis in ATO-treated Calu-6 cells. Apoptosis is closely related to the collapse of MMP $\left(\Delta \Psi_{\mathrm{m}}\right)(26)$, and ATO can cause a breakdown in MMP $\left(\Delta \Psi_{\mathrm{m}}\right)$ (29-31). Correspondingly, ATO induced the loss of MMP $\left(\Delta \Psi_{\mathrm{m}}\right)$ in HeLa, CPAEC and HUVEC. The loss of MMP $\left(\Delta \Psi_{\mathrm{m}}\right)$ in ATO-treated HUVEC was less than that in CPAEC. As expected from the annexin $\mathrm{V}$ assay results, MMP $\left(\Delta \Psi_{\mathrm{m}}\right)$ loss in A549 and HPF cells was not triggered by ATO. Notably, ATO-treated Calu- 6 cells showed some loss in MMP $\left(\Delta \Psi_{\mathrm{m}}\right)$ without the strong induction of apoptosis. These results imply that ATO first damages mitochondria in HeLa, Calu-6 and CPAEC in order to proceed to the next step of apoptosis, but ATO does not initially destroy mitochondria in HUVEC. In addition, these results suggest that the differences in sensitivity to ATO in various cell types in relation to apoptosis and MMP $\left(\Delta \Psi_{\mathrm{m}}\right)$ are probably due to the different basal activities of mitochondria depending on cell type, tissue origin and species (32).

ATO can disturb the natural oxidation and reduction equilibrium in cells, leading to an increase in ROS by a variety of redox enzymes, including flavoprotein-dependent superoxide-producing enzymes such as nicotine adenine diphosphate oxidase $(33,34)$. The increased intracellular ROS is observed in ATO-treated cervical cancer cells (35), APL cells (36), hepatocellular carcinoma HepG2 (37), and glioblastoma A172 cells (16). These results suggest that ATOinduced cell death is related to ROS accumulation. However, according to our results, 5 or $10 \mu \mathrm{M}$ ATO triggering apoptosis in HeLa cells decreased the ROS level whereas 20 or $50 \mu \mathrm{M}$ ATO increased the ROS level. ATO commonly increased the ROS level in Calu- 6 cells without the convincible induction of apoptosis. Treatment with $1 \mu \mathrm{M}$ ATO increased the ROS level without apoptosis in A549 cells whereas $50 \mu \mathrm{M}$ ATO decreased the ROS level. The relatively higher doses of ATO increased the ROS level in CPAEC but decreased the ROS level in HUVEC. In addition, the higher dose of $50 \mu \mathrm{M}$ ATO increased the ROS level but slightly induced apoptosis in HPF cells. Similarly, results from Haga et al showed that ROS accumulation was detected in ATO-treated glioblastoma T98G cells but apoptosis did not occur in these cells (16). We also prevously showed that ATO reduced intracellular ROS levels in As4.1 juxtaglomerular cells (24). In relation to the $\mathrm{O}_{2}{ }^{-}$level in ATO-treated cells, an increased pattern in $\mathrm{O}_{2}{ }^{-}$ levels following treatment with ATO was reported in esophageal cancer SHEE85 (38) and As4.1 juxtaglomerular cells (24), but this pattern was not observed in ATO-treated acute myelogenous leukemia HL-60 (39) and renal cell carcinoma ACHN cells (40). According to our results, the $\mathrm{O}_{2}^{--}$level was increased in ATO-treated HeLa and Calu- 6 cells. In contrast, all the tested doses of ATO decreased $\mathrm{O}_{2}^{-{ }^{-}}$levels in A549 cells. While the dose of $10 \mu \mathrm{M}$ ATO decreased $\mathrm{O}_{2}{ }^{-}$ levels in both CPAEC and HUVEC, higher doses of ATO increased the levels. Treatment with $>5 \mu \mathrm{M}$ ATO increased $\mathrm{O}_{2}{ }^{--}$levels in HPF cells, but the increase was not dosedependent. Taken together, these results imply that treatment 
with ATO differentially affects ROS levels depending on the incubation dose and cell type, and cell death by ATO is not tightly correlated to changes in ROS levels.

In relation to the GSH level in ATO-treated cells, ATO decreases GSH levels in certain APL cells (41). Likewise, relatively higher doses of ATO inducing apoptosis in HeLa cells, CPAEC and HUVEC deceased the GSH level. However, 10 or $20 \mu \mathrm{M}$ ATO triggering apoptosis in HeLa cells increased the GSH level, and 5 or $10 \mu \mathrm{M}$ ATO did not reduce the GSH level in CPAEC. In addition, lower doses of ATO decreased GSH levels in Calu-6 cells whereas higher doses of ATO increased these levels. In ATO-treated A549 cells, the GSH level was not strongly altered. The relatively lower doses of 1-10 $\mu \mathrm{M}$ ATO increased GSH levels in HPF cells, and higher doses of ATO slightly inducing apoptosis did not change the level. These results also suggest that ATO increased or decreased GSH levels without the tight relationship with changes in the ROS level depending on the incubation dose and cell type.

In conclusion, we demonstrated that ATO differentially affected the growth inhibition and cell death in the tested cells depending on the incubation dose and cell type. ATO also increased or decreased ROS and GSH levels in the tested cells, and these changes in levels were not tightly correlated with the level of cell death. Our present data provide useful information regarding the action of ATO in various cell types including normal cells in relation to cell growth, cell death, ROS and GSH levels.

\section{Acknowledgements}

This research was supported by a grant of the Korea Healthcare Technology R\&D Project, Ministry for Health, Welfare and Family Affairs and the Republic of Korea (A084194) as well as the Korea Research Foundation Grant from the Government of the Republic of Korea (MOEHRD).

\section{References}

1. Soignet SL, Maslak P, Wang ZG, Jhanwar S, Calleja E, Dardashti LJ, Corso D, DeBlasio A, Gabrilove J, Scheinberg DA, et al: Complete remission after treatment of acute promyelocytic leukemia with arsenic trioxide. N Engl J Med 339: 1341-1348, 1998

2. Park WH, Seol JG, Kim ES, Hyun JM, Jung CW, Lee CC Kim BK and Lee YY: Arsenic trioxide-mediated growth inhibition in MC/CAR myeloma cells via cell cycle arrest in association with induction of cyclin-dependent kinase inhibitor, p21, and apoptosis. Cancer Res 60: 3065-3071, 2000.

3. Zhang W, Ohnishi K, Shigeno K, Fujisawa S, Naito K, Nakamura S, Takeshita K, Takeshita A and Ohno R: The induction of apoptosis and cell cycle arrest by arsenic trioxide in lymphoid neoplasms. Leukemia 12: 1383-1391, 1998.

4. Wang ZG, Rivi R, Delva L, Konig A, Scheinberg DA, Gambacorti-Passerini C, Gabrilove JL, Warrell RP Jr and Pandolfi PP: Arsenic trioxide and melarsoprol induce programmed cell death in myeloid leukemia cell lines and function in a PML and PML-RARalpha independent manner. Blood 92: 1497-1504, 1998.

5. Hyun Park W, Hee Cho Y, Won Jung C, Oh Park J, Kim K, Hyuck Im Y, Lee MH, Ki Kang W and Park K: Arsenic trioxide inhibits the growth of A498 renal cell carcinoma cells via cel cycle arrest or apoptosis. Biochem Biophys Res Commun 300: 230-235, 2003

6. Seol JG, Park WH, Kim ES, Jung CW, Hyun JM, Kim BK and Lee YY: Effect of arsenic trioxide on cell cycle arrest in head and neck cancer cell line PCI-1. Biochem Biophys Res Commun 265 400-404, 1999.
7. Uslu R, Sanli UA, Sezgin C, Karabulut B, Terzioglu E, Omay SB and Goker E: Arsenic trioxide-mediated cytotoxicity and apoptosis in prostate and ovarian carcinoma cell lines. Clin Cancer Res 6: 4957-4964, 2000.

8. Oketani M, Kohara K, Tuvdendorj D, Ishitsuka K, Komorizono Y, Ishibashi $\mathrm{K}$ and Arima $\mathrm{T}$ : Inhibition by arsenic trioxide of human hepatoma cell growth. Cancer Lett 183: 147-153, 2002.

9. Kito M, Akao Y, Ohishi N, Yagi K and Nozawa Y: Arsenic trioxide-induced apoptosis and its enhancement by buthionine sulfoximine in hepatocellular carcinoma cell lines. Biochem Biophys Res Commun 291: 861-867, 2002.

10. Pu YS, Hour TC, Chen J, Huang CY, Guan JY and Lu SH: Cytotoxicity of arsenic trioxide to transitional carcinoma cells. Urology 60: 346-350, 2002.

11. Nakagawa Y, Akao Y, Morikawa H, Hirata I, Katsu K, Naoe T, Ohishi N and Yagi K: Arsenic trioxide-induced apoptosis through oxidative stress in cells of colon cancer cell lines. Life Sci 70: 2253-2269, 2002

12. Li M, Cai JF and Chiu JF: Arsenic induces oxidative stress and activates stress gene expressions in cultured lung epithelial cells. J Cell Biochem 87: 29-38, 2002.

13. Baj G, Arnulfo A, Deaglio S, Mallone R, Vigone A, De Cesaris MG, Surico N, Malavasi F and Ferrero E: Arsenic trioxide and breast cancer: analysis of the apoptotic, differentiative and immunomodulatory effects. Breast Cancer Res Treat 73: 61-73, 2002.

14. Woo SH, Park IC, Park MJ, Lee HC, Lee SJ, Chun YJ, Lee SH, Hong SI and Rhee $\mathrm{CH}$ : Arsenic trioxide induces apoptosis through a reactive oxygen species-dependent pathway and loss of mitochondrial membrane potential in HeLa cells. Int J Oncol 21: 57-63, 2002.

15. Zhang TC, Cao EH, Li JF, Ma W and Qin JF: Induction of apoptosis and inhibition of human gastric cancer MGC-803 cell growth by arsenic trioxide. Eur J Cancer 35: 1258-1263, 1999.

16. Haga N, Fujita $\mathrm{N}$ and Tsuruo T: Involvement of mitochondrial aggregation in arsenic trioxide $\left(\mathrm{As}_{2} \mathrm{O}_{3}\right)$-induced apoptosis in human glioblastoma cells. Cancer Sci 96: 825-833, 2005.

17. Gonzalez C, Sanz-Alfayate G, Agapito MT, Gomez-Nino A, Rocher A and Obeso A: Significance of ROS in oxygen sensing in cell systems with sensitivity to physiological hypoxia. Respir Physiol Neurobiol 132: 17-41, 2002.

18. Baran CP, Zeigler MM, Tridandapani S and Marsh CB: The role of ROS and RNS in regulating life and death of blood monocytes. Curr Pharm Des 10: 855-866, 2004.

19. Bubici C, Papa S, Pham CG, Zazzeroni F and Franzoso G: The NF-kappaB-mediated control of ROS and JNK signaling. Histol Histopathol 21: 69-80, 2006

20. Poot M, Teubert H, Rabinovitch PS and Kavanagh TJ: De novo synthesis of glutathione is required for both entry into and progression through the cell cycle. J Cell Physiol 163: 555-560, 1995.

21. Schnelldorfer T, Gansauge S, Gansauge F, Schlosser S, Beger HG and Nussler AK: Glutathione depletion causes cell growth inhibition and enhanced apoptosis in pancreatic cancer cells. Cancer 89: 1440-1447, 2000.

22. Lauterburg BH: Analgesics and glutathione. Am J Ther 9 : 225-233, 2002 .

23. Han YH, Kim SZ, Kim SH and Park WH: Apoptosis in pyrogallol-treated Calu- 6 cells is correlated with the changes of intracellular GSH levels rather than ROS levels. Lung Cancer 59: 301-314, 2008.

24. Han YH, Kim SZ, Kim SH and Park WH: Arsenic trioxide inhibits growth of As4.1 juxtaglomerular cells via cell cycle arrest and caspase-independent apoptosis. Am J Physiol Renal Physiol 293: F511-F520, 2007

25. Han YH, Kim SH, Kim SZ and Park WH: Caspase inhibitor decreases apoptosis in pyrogallol-treated lung cancer Calu-6 cells via the prevention of GSH depletion. Int J Oncol 33: 1099-1105, 2008

26. Yang J, Liu X, Bhalla K, Kim CN, Ibrado AM, Cai J, Peng TI, Jones DP and Wang X: Prevention of apoptosis by Bcl-2: release of cytochrome c from mitochondria blocked. Science 275: 1129-1132, 1997

27. Shao W, Fanelli M, Ferrara FF, Riccioni R, Rosenauer A, Davison K, Lamph WW, Waxman S, Pelicci PG, Lo Coco F, et al: Arsenic trioxide as an inducer of apoptosis and loss of PML/RAR alpha protein in acute promyelocytic leukemia cells. J Natl Cancer Inst 90: 124-133, 1998

28. Ling YH, Jiang JD, Holland JF and Perez-Soler R: Arsenic trioxide produces polymerization of microtubules and mitotic arrest before apoptosis in human tumor cell lines. Mol Pharmacol 62: 529-538, 2002 
29. Pham NA, Robinson BH and Hedley DW: Simultaneous detection of mitochondrial respiratory chain activity and reactive oxygen in digitonin-permeabilized cells using flow cytometry. Cytometry 41: 245-251, 2000.

30. Campo ML, Kinnally KW and Tedeschi H: The effect of antimycin A on mouse liver inner mitochondrial membrane channel activity. J Biol Chem 267: 8123-8127, 1992

31. Balaban RS, Nemoto S and Finkel T: Mitochondria, oxidants, and aging. Cell 120: 483-495, 2005

32. Oberley LW and Oberley TD: Role of antioxidant enzymes in cell immortalization and transformation. Mol Cell Biochem 84 147-153, 1988

33. Chou WC, Jie C, Kenedy AA, Jones RJ, Trush MA and Dang CV: Role of NADPH oxidase in arsenic-induced reactive oxygen species formation and cytotoxicity in myeloid leukemia cells. Proc Natl Acad Sci USA 101: 4578-4583, 2004.

34. Miller WH Jr, Schipper HM, Lee JS, Singer J and Waxman S: Mechanisms of action of arsenic trioxide. Cancer Res 62: 3893-3903, 2002.

35. Kang YH, Yi MJ, Kim MJ, Park MT, Bae S, Kang CM, Cho CK, Park IC, Park MJ, Rhee $\mathrm{CH}$, et al: Caspase-independent cell death by arsenic trioxide in human cervical cancer cells: reactive oxygen species-mediated poly(ADP-ribose) polymerase-1 activation signals apoptosis-inducing factor release from mitochondria. Cancer Res 64: 8960-8967, 2004
36. Jing Y, Dai J, Chalmers-Redman RM, Tatton WG and Waxman S: Arsenic trioxide selectively induces acute promyelocytic leukemia cell apoptosis via a hydrogen peroxide-dependent pathway. Blood 94: 2102-2111, 1999.

37. Li JJ, Tang Q, Li Y, Hu BR, Ming ZY, Fu Q, Qian JQ and Xiang JZ: Role of oxidative stress in the apoptosis of hepatocellular carcinoma induced by combination of arsenic trioxide and ascorbic acid. Acta Pharmacol Sin 27: 1078-1084, 2006.

38. Shen ZY, Shen WY, Chen MH, Shen J and Zeng Y: Reactive oxygen species and antioxidants in the apoptosis of esophageal cancer cells induced by $\mathrm{As}_{2} \mathrm{O}_{3}$. Int $\mathrm{J}$ Mol Med 11: 479-484, 2003.

39. Han SS, Kim K, Hahm ER, Park CH, Kimler BF, Lee SJ, Lee SH, Kim WS, Jung CW, Park K, et al: Arsenic trioxide represses constitutive activation of NF-kappaB and COX-2 expression in human acute myeloid leukemia, HL-60. J Cell Biochem 94: 695-707, 2005

40. Wu XX, Ogawa O and Kakehi Y: Enhancement of arsenic trioxide-induced apoptosis in renal cell carcinoma cells by L-buthionine sulfoximine. Int J Oncol 24: 1489-1497, 2004.

41. Dai J, Weinberg RS, Waxman S and Jing Y: Malignant cells can be sensitized to undergo growth inhibition and apoptosis by arsenic trioxide through modulation of the glutathione redox system. Blood 93: 268-277, 1999 